\title{
Detection of Stress among Workers in a Cement Factory
}

\author{
By
}

\author{
El-Khayat M', Mohamed-Hussein A ${ }^{2}$, Ezzeldien A ${ }^{3}$, Zayet $\mathbf{H H}^{4}$
}

\author{
and Ibrahim AK ${ }^{1}$ \\ ${ }^{1}$ Department of Community Medicine, ${ }^{2}$ Department of Chest, ${ }^{3}$ Department of Clinical \\ Pathology, Assiut University, Assuit, ${ }^{4}$ Department of Occupational and Environmental \\ Medicine, Cairo University, Cairo, Egypt
}

Corresponding Author: El-Khayat M: mariam.elkhayat@aun. edu.eg

\begin{abstract}
Introduction: Stress is one of the most important work-related psychological health problems. Occupational stress is defined as harmful physical and emotional responses incurred in work environment. Recently, researches focused more on the impact of the psychosocial work environment on health more than physical hazards in the workplace. As a lot of economic problems can result from mental problems among workers such as raising absenteeism, decrease productivity, expensive treatment and labor compensation claims. Aim of work: To study the stress condition among workers in a cement factory in Upper Egypt, and to detect vulnerable workers for stress. Materials and methods:A cross-sectional study was performed included 86 workers from main four departments (quarry, production, packing and maintenance). Pre-designed questionnaire was answered, including personal and occupational histories and specific questions to assess stress; extracted from Job Stress Questionnaire (JSQ), which was created in a study specially made by Japanese Ministry of Health, Labor and Welfare. Persons with a total score for physical stress response of 25 points or more are considered to have physical stress response. Results: The current study showed that nearly half of the studied group was current smokers, $22 \%$ worked as farmers in their weekend, $95 \%$ of workers were categorized in low physical job stress response. The mean of job stress score of all studied workers was $14.9 \pm 4.8$, recording highest score 32 and lowest score 11. However, when comparing the job stress difference among workers according to different characteristic; there was statistically significant relationship between job stress and department distribution, duration of exposure, presence of respiratory complains and residency $(\mathrm{p}<$ 0.05).Conclusion: Nearly most of the studied workers (95\%) were categorized among low job stress group. However the most vulnerable groups for stress were maintenance workers, workers with respiratory complains, workers with high duration of exposure "more than 20 years", workers resident in urban areas, and supervisors.
\end{abstract}

Key words: Stress, Job Stress Questionnaire (JSQ), Cement, Occupation and Residency. 


\section{Introduction}

Over recent decades, there has been a shift in the focus of occupational health from physical hazards in the workplace to the impact of the psychosocial work environment on health. The psychosocial environment at work and its effect on health continues to be an important factor (Stansfeld et al. 2011). Stress is one of the most important work-related psychological health problems (Eurostat 2010). Occupational stress is defined as harmful physical and emotional responses incurred in work environment (Luo et al. 2016). WHO defined work-related stress is the response of people when presented with work demands and pressures, that are not matched to their knowledge and abilities and which challenge their ability to cope. Work-related stress can be caused by poor work organization, by poor work design, poor management, unsatisfactory working conditions, and lack of support from colleagues and supervisors (WHO 2019). Studies have shown that short periods of exposure to psychosocial hazards and stress are associated with reactions such as sleep disturbance, changes in mood, fatigue, headaches and stomach irritability (Beswick et al. 2006). Prolonged exposure to psychosocial hazards has been shown to be associated with a wide range of mental and physical health outcomes, including anxiety, depression, suicide attempts, sleep problems, back pain, chronic fatigue, digestive problems, autoimmune disease, poor immune function, cardiovascular disease, high blood pressure and peptic ulcers (Cohena et al. 2012). The financial implications of work-related stress and psychosocial risks are associated with deterioration of productivity, higher levels of absenteeism and employee turnover. In the United Kingdom, in 2011/12, work-related stress caused workers to lose 10.4 million working days, and workers were absent for on average 24 days(EU-OSHA 2014). Other studies showed that about a fifth of staff turnover can be related to stress at work (CIPD 2008), and that among employees who state that they 'always work under pressure', the accident rate is about five times higher than that of employees who are 'never' subject to pressurized work(EU-OSHA 2014). At a societal level, ill health associated with chronic work-related stress and prolonged exposure to psychosocial risks at work can strain national health services and reduce economic productivity, having a negative impact on a country's gross domestic product GDP (Bejean and Sultan-Taieb 2005). 


\section{Aim of work}

To study the stress condition among workers in a cement factory in Upper Egypt and also to detect vulnerable workers for stress.

\section{Materials and methods}

Study design: It is a descriptive cross sectional study.

Place and duration of study: the study was carried out in a cement factory in Upper Egypt during the period from March to September 2018

Study sample: Total coverage of all workers attended the occupational health clinic in a cement factory in Upper Egypt. They were 86 males, their ages ranged between 25-46 years. Inclusion criteria included all workers who accept to fill the questionnaire and workers with minimum 2 years of experience in the studied factory. Exclusion criteria included workers paid by day to prevent problems with the tracking.

\section{Study methods:}

\section{1-Pre-designed Questionnaire:}

Full history was taken by the authors according to a pre-designed questionnaire, including personal, occupational histories and specific questions to assess stress extracted from Job Stress Questionnaire (JSQ), which was created in a study commissioned by Japanese Ministry of Health, Labor and Welfare; we used only one of two parts which is physical stress response. The Questionnaire has been shown to have Cronbach a coefficient of 0.81 for physical stress response (Kato, 2000)

\section{2- To assess Physical Stress} Response, we used 11 items; each item was rated on a four point scale ranging from "never" to "nearly all time". Persons with a total score of 25 points or more are considered to have physical stress response (Sakakibara 2006).

\section{Consent}

An informed verbal consent was taken from workers who agreed to participate in the study before the start of work with assurance of confidentiality of data.

\section{Ethical approval}

Approval of the administrative authority of the company was obtained. The study protocol was approved by the Ethical Committee of Assiut Faculty of Medicine.

\section{Data management}

Data were analyzed using SPSS 22. The mean values, standard deviation (SD) were estimated for quantitative variables. Comparisons between the different groups were done using Chi Square test for qualitative variables, and independent samples t- test for normally distributed quantitative variables. $\mathrm{P}$ values less than $0.05(p<0.05)$ were considered statistically significant. 


\section{Results}

Table (1): Some demographic characteristics of the studied group.

\begin{tabular}{|c|c|c|}
\hline Characteristics & Frequency $(\mathrm{No}=86)$ & $(\%)$ \\
\hline \multicolumn{3}{|l|}{ Age / years: } \\
\hline - $\quad<30$ & 7 & $8.1 \%$ \\
\hline - $30-$ & 14 & $16.3 \%$ \\
\hline - $40-$ & 35 & $40.7 \%$ \\
\hline - $\quad \geq 50$ & 30 & $34.9 \%$ \\
\hline \multicolumn{3}{|l|}{ Residence: } \\
\hline - Urban & 36 & $41.9 \%$ \\
\hline - $\quad$ Rural & 50 & $58.1 \%$ \\
\hline \multicolumn{3}{|l|}{ Job nature: } \\
\hline - $\quad$ Manual Worker & 23 & $26.7 \%$ \\
\hline - $\quad$ Technician & 32 & $37.2 \%$ \\
\hline - $\quad$ Engineer & 10 & $11.6 \%$ \\
\hline - $\quad$ Driver & 4 & $4.7 \%$ \\
\hline - $\quad$ Supervisor & 17 & $19.8 \%$ \\
\hline \multicolumn{3}{|c|}{ Distribution of workers according to departments: } \\
\hline - $\quad$ Production & 23 & $26.8 \%$ \\
\hline - $\quad$ Quarry & 15 & $17.4 \%$ \\
\hline - $\quad$ Packing & 21 & $24.4 \%$ \\
\hline - $\quad$ Maintenance & 27 & $31.4 \%$ \\
\hline \multicolumn{3}{|l|}{ Smoking History: } \\
\hline - $\quad$ Never smoker & 38 & $44.2 \%$ \\
\hline - $\quad$ Current smoker & 40 & $46.5 \%$ \\
\hline - $\quad$ Ex-smoker\# & 8 & $9.3 \%$ \\
\hline
\end{tabular}

\#workers who had quit smoking for at least 1 year

Table 1 showed that $41 \%$ of the studied workers were in the age group " 40 49 " years old and other $35 \%$ of workers were above 50 years. They had different job nature as follows; nearly one-quarter of studied sample were manual workers (26.8\%), one-third were technicians $(37.2 \%)$, one-fifth were supervisors $(19.8 \%)$ and the rest were engineers $(11.6 \%)$ and drivers $(4.7 \%)$. They were distributed on the four main departments; $26.8 \%$ in the production unit, $17.4 \%$ in quarry, $24.4 \%$ in packing and $31.4 \%$ in maintenance. About half of them were smokers. 
Table (2): Occupational history of the studied group.

\begin{tabular}{|c|c|c|}
\hline Characteristics & $\begin{array}{r}\text { Frequency } \\
(\mathbf{N o}=\mathbf{8 6})\end{array}$ & $(\%)$ \\
\hline \multicolumn{3}{|l|}{ Duration of work/ years } \\
\hline - $\quad<10$ & 7 & $8.1 \%$ \\
\hline - $10-20$ & 30 & $34.9 \%$ \\
\hline - $\quad \geq 20$ & 49 & $57.0 \%$ \\
\hline Previous job history: & 26 & $30.2 \%$ \\
\hline - High risk respiratory affection\# & 18 & $69.2 \%$ \\
\hline - Low risk respiratory affection\# & 8 & $30.8 \%$ \\
\hline \multicolumn{3}{|l|}{ Another job in weekend } \\
\hline - $\mathrm{NO}$ & 64 & $74.4 \%$ \\
\hline - $\quad$ Farming & 19 & $22.1 \%$ \\
\hline - $\quad$ Others\#\# & 3 & $3.5 \%$ \\
\hline \multicolumn{3}{|c|}{$\begin{array}{l}\text { \#: Previous dust exposure } \# \text { : Painters and builders } \\
\text { Table } 2 \text { showed that one-third of the studied group ( } 30.2 \%) \text { had previous job } \\
\text { before joining the studied factory; two-thirds of them had previous high risk jobs } \\
\text { of respiratory affection. Almost one-quarter of workers were working as farmers in } \\
\text { their weekend. }\end{array}$} \\
\hline \multicolumn{3}{|c|}{ Table (3): Physical job stress among the studied group. } \\
\hline Characteristic & $\begin{array}{c}\text { Frequency } \\
\qquad N_{0}=86\end{array}$ & $\%$ \\
\hline \multicolumn{3}{|l|}{ Physical stress response categories: } \\
\hline -High physical stress response $\geq 25$ & 4 & $4.7 \%$ \\
\hline -Low physical stress response $<25$ & 82 & $95.3 \%$ \\
\hline \multicolumn{3}{|l|}{ Job stress score } \\
\hline Mean \pm SD & \multicolumn{2}{|c|}{$14.9 \pm 4.8$} \\
\hline Median (Min.-Max.) & \multicolumn{2}{|c|}{$13(11-32)$} \\
\hline
\end{tabular}

Table 3 revealed that only 4 workers had high physical stress, thus almost of workers $(95.3 \%)$ had low physical stress response. As the mean of job stress score of all studied workers was $14.9 \pm 4.8$, recording highest score 32 and lowest score 11. 
Table (4): Differences in job stress of the studied group according to different characteristics.

\begin{tabular}{|c|c|c|}
\hline Characteristics & $\begin{array}{c}\text { Job stress score } \\
\text { Mean } \pm \text { SD }\end{array}$ & p -value \\
\hline \multicolumn{3}{|l|}{ Departments: } \\
\hline - $\quad$ Quarry & $12.8 \pm 2.4$ & \multirow{4}{*}{$0.03 *$} \\
\hline - $\quad$ Production & $14.9 \pm 5.9$ & \\
\hline - $\quad$ Packing & $14.9 \pm 3.2$ & \\
\hline - Maintenance & $16.2 \pm 5.3$ & \\
\hline \multicolumn{2}{|l|}{ Duration of exposure to cement / years } & \multirow{4}{*}{$0.05 *$} \\
\hline - $\quad<10$ & $11.7 \pm 0.9$ & \\
\hline - $10-20$ & $15.1 \pm 5.4$ & \\
\hline - $\quad \geq 20$ & $15.3 \pm 4.5$ & \\
\hline \multicolumn{3}{|l|}{ Respiratory complaint } \\
\hline - Workers with respiratory complaint & $16.1 \pm 5.2$ & \multirow{2}{*}{$0.01 *$} \\
\hline - Workers with no respiratory complaint & $13.9 \pm 4.0$ & \\
\hline \multicolumn{3}{|l|}{ Residence } \\
\hline - Urban & $16.3 \pm 5.0$ & \multirow{2}{*}{$0.01 *$} \\
\hline - $\quad$ Rural & $14 \pm 4.3$ & \\
\hline
\end{tabular}

*: Statistically significant

Table 4 showed that there was statistically significant difference between job stress and department distribution, working experience, presence of respiratory complains and residency $(p<0.05)$. Workers in the maintenance department had the highest significant job stress score $(16.2 \pm 5.3)$, followed by workers in production and packing and finally workers in quarry had the least job stress score $12.8 \pm 2.4$. Also, workers with experience more than 20 years and 10-19 years had higher significant job stress score than workers with experience less than 10 years. Likely workers with respiratory complaint had higher significant stress score mean (16.1 $\pm 5.2)$ than workers with no complaint $(13.9 \pm 4.0)$. Finally workers resident in urban areas had statistically significant higher job stress score with mean $16.3 \pm 5.0$ compared to workers lived in rural areas. 


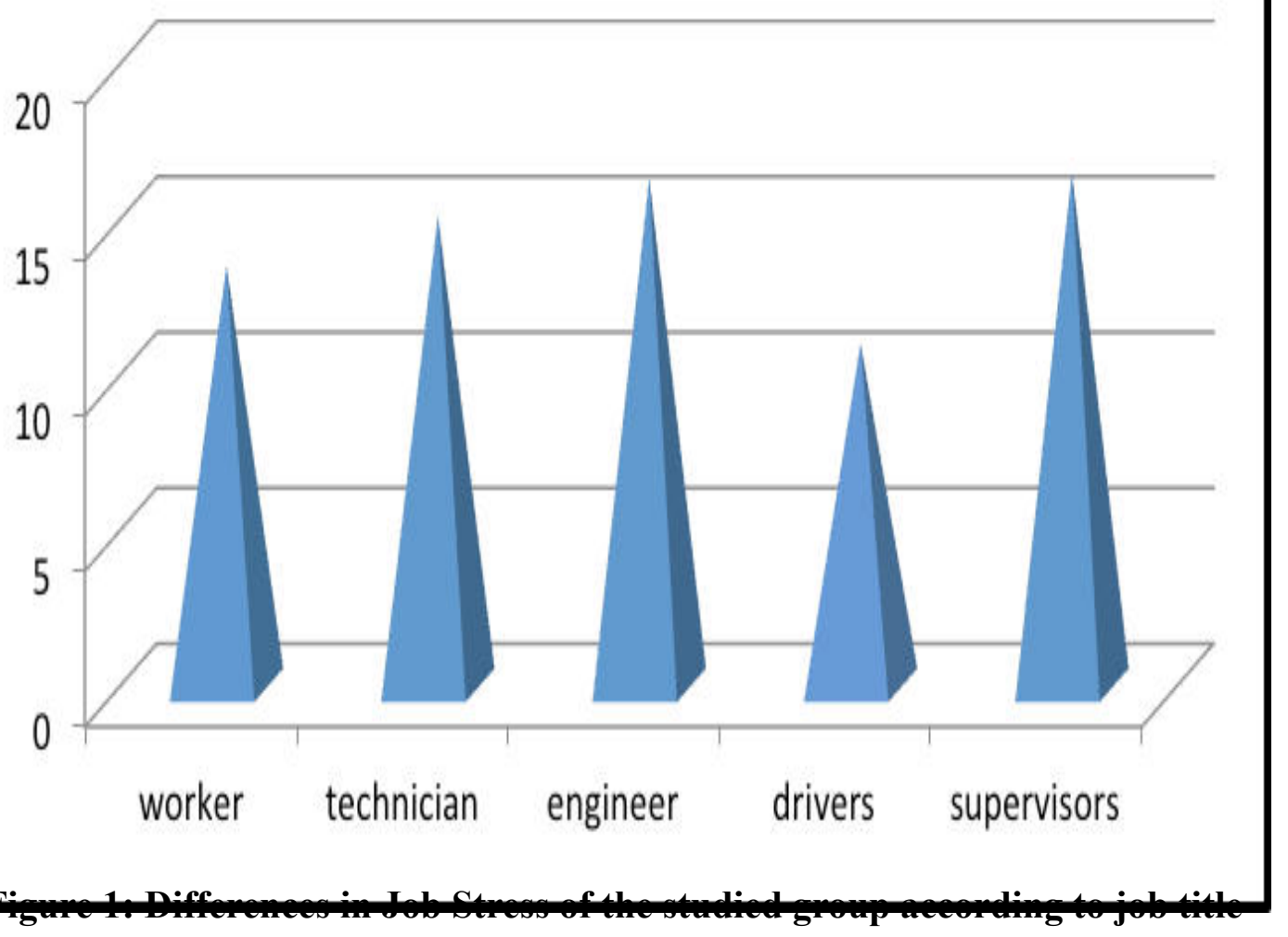

Figure 1 illustrated that job nature was found to had an effect on job stress score, as supervisors had the highest significant score followed by engineers, technician, workers and finally drivers, with statistically significance difference $(\mathrm{p}<0.05)$. 


\section{Discussion}

Occupation is a key factor affecting the health-related quality of life. Occupational environments consist of physical, mental, and social stimuli, each of which may be regarded as a stress factor. These stresses have detrimental effects on both physical and mental health (Faragher et al. 2005). Considering the poor work conditions in the factories of developing countries, the routine life of workers may be adversely affected by environmental factors in various aspects, such as physical, mental, social, and economic. Hence, the concept of health-related quality of life becomes significant in these people (Mohammadi et al. 2017).

In the current study, the prevalence of smoking was high, nearly half of studied workers were current smoker ( Table 1), compared with a previous study in the same factory where only one-third were smokers (Morsy 1995) .This smoking prevalence attract the attention to arrange for health education program for prevention and control. Moreover, smoking prevalence in our study was nearly similar to other studies as in Norway (Fell et al. 2011) and Iran (Neghab and choobineh 2007) but higher than an Ethiopian study which found that only $12 \%$ were smokers (Gizaw et al. 2016), in Thailand (Thepaksorn et al. 2013) where only one-third of the exposed workers were smokers, and a UAE study with only one-fifth were smokers (Ahmed and Abdullah 2012). In the opposite side, a study in Taiwan reported that about two-thirds of the studied sample was smokers (Wen et al. 2005).

According to residence, we found that nearly $60 \%$ of workers lived in rural areas and about one-fifth worked as farmer during their weekend (Table1). This was matched with another study done in India, North Karnataka ( Manjula et al. 2013) on the effects of occupational dust exposure on the health status of Portland cement factory workers and they detected about two-third lived in urban and 33\% had rural residency.

Concerning previous experience before joining the current work, it was found that about one-third of the studied workers had previous experience and two-thirds of them had previous risky work (high dusty areas) (Table 2). This was in line with multicenter study conducted in eight European countries, and found that about $40 \%$ of workers in the 24 factories had previous exposure to either gas or dust before joining the cement factories (Nordby et al. 2011). 
Regarding stress condition of the studied workers, nearly most of them $(95 \%)$ were in low-job stress response category (Table 3 ), this was consistent with a study carried out by Stansfeld et al. 2011 in their study on the relation between occupation and mental health in a national UK survey, which documented lower mental disorders among machine and industrial operators, because these occupations can be self maintained and may not have high levels of psychological demands that are a risk factor for common mental disorder .

However, when comparing job stress score among workers in relation to their department distribution, workers in the maintenance sector reported the significant highest scores, followed by workers in production and packing sectors, finally workers in quarry had the least score ( Table 4). This means that job tasks with higher mental effort as maintenance is more stressful than tasks which need more physical activity like quarry. So high psychological demands may be important contributors to the higher risk of mental disorder in these occupations (Stansfeld et al. 2011). Maintenance workers usually settled in electrical and mechanical workshop, and entered the field when there is a problem; this was supported by a Korean study, as they found that employment in an office job was associated with a two folds increase in the odds of anxiety compared to a manufacturing job (Kang et al. 2016).

Workers with higher exposure duration "more than 20 years" had higher statistically significant job stress score compared to workers with exposure duration less than 10 years (Table 4), this could be explained as younger workers had higher workfamily enrichment, job satisfaction, and vigor, also they had more ability to buffered against negative outcomes related to job insecurity unlike older (Mauno et al. 2013). This was inconsistent with other study done in Spain, which deduced that the more experience the workers had, the higher liveliness and mental health scores they got; they were explaining that with more experience, the quality of life increases, so the workers experience happiness out of their works, especially with more accepting their working environments (Demirbag et al. 2017) . Other studies showed that age and years of experience had no effect on life quality made with SF-36 scale ( Kurban et al. 2012 and Gholami et al. 2013) 
In the current study, workers with respiratory complains had higher job stress score than workers with no respiratory complain with statistically significance difference $(p=0.009)$ (Table 3). This indicated that the presence of respiratory symptoms was associated with more stress, which may be explained by that pro-inflammatory cytokines (i.e. IL-6) production can be directly stimulated by depression and other negative emotions and stressful experiences. Indeed, both physical and psychological stressors can provoke transient increases in pro-inflammatory cytokines. Overproduction of IL-6, is related to increase respiratory affection (Kiecolt-Glaser et al. 2003).

Likewise, residency was found to be correlated with job stress in the present study. Urban resident workers had higher job stress score compared to workers leaving in rural areas, with statistically significance difference $(\mathrm{p}=0.008)(\mathrm{Ta}-$ ble 4). This may be related to the noise and pollution that were more prevalent in urban areas (EEAA 2010). This was supported by Srivastava K 2009, who confirms the strong association between urbanization and mental disorders. On the other side, this was inconsistent with a study from Turkey done by Demirbag et al. 2017 on the evaluation of the life quality of workers in a cement factory, and found that there was no effect of residence on life quality of the studied workers, this could be explained by the efforts done by ministry of health in Turkey to reach the equity in health services in all areas (urban and rural) thus affecting behavior disorders (Bener et al. 2019).

Conclusion: In spite of low job stress scores among the studied workers, but distribution in specific departments, job nature, residency, high exposure duration "more than 20 years" and presence of respiratory complains had statistically significant effect on stress. So these factors must be taken into consideration. The most vulnerable groups for stress were maintenance workers, workers with respiratory complains, workers with high experience, workers who are living in urban areas, and supervisors.

Recommendations: Smoking quit program is recommended to be applied in factories, also stress releasing programs is suggested to more vulnerable groups to stress.

\section{Conflict of interest}

Authors have declared that no conflict of interest exists.

\section{Funding}

There was no source of funding.

\section{Acknowledgement}

The authors would like to acknowledge all individuals who participated in this study. 


\section{References}

1- Ahmed H and Abdullah A (2012): Dust Exposure and Respiratory Symptoms among Cement Factory Workers in the United Arab Emirates. Industrial Health; 50: $214-22$.

2- Bejean S and Sultan-Taieb H (2005): Modeling the economic burden of diseases imputable to stress at work. European Journal of Health Economics; 50: 16-23.

3- Beswick J, Gore $\mathrm{G}$ and Palferman D (2006): Bullying at work: a review of the literature. Health and Safety Laboratories. Available at: http://www.workstress.net/ sites/default/files/literature_review.pdf.

4- CIPD (Chartered Institute of personnel and Development) (2008): Recruitment, retention and turnover. Available at: http://www.cipd.co.uk/ NR/rdonlyres/BE3 C 57 B F - 91 F F 4AD $0-9656$-FAC27E 5398 A A / 0 / recruitmentretentionturnover2008.pdf.

5- Cohena S, Janicki-Devertsa D, Doyleb W, Millerc G, Frankd E, et al (2012): Chronic stress, glucocorticoid receptor resistance, inflammation, and disease risk. PNAS; 109(16): 5995-9.

6- Demirbag B, Bayrak B, Ozkan C and Caylak E( 2017) Evaluation of the Life Quality of Workers In A Cement Factory Procedia - Social and Behavioral Sciences; 237: $1462-7$.
7- EEAA (Egyptian Environmental Affairs Agency)(2010). Egypt State ofEnvironment 2010.Egyptian Environmental Affairs Agency. Available at: http://www.eeaa. gov.eg/portals/0/eeaaReports/SoE2011en/ completereport/SOE-2010-En.pdf

8- Bener A, Alayoglu N, Catan F, Torun P and Yilmaz E (2019): Health Services Management in Turkey: Failure or Success? Int J Prev Med; 10(1):30.

9- EU-OSHA(European Union- Occupational Safety and Health Agency) (2014): Calculating the cost of work-related stress and psychosocial risks. European Risk Observatory. Literature Review. Luxembourg: European Agency for Safety and Health at Work. Available at: https:// osha.europa.eu/en/tools-and publications/ publications/literature_reviews/ calculating-the-cost-of-work-relatedstress-and-psychosocial-risks.

10- Eurostat (2010): Health and safety at work in Europe (1999-2007): A statistical portrait In: European Commission. Luxembourg: Publications Office of the European Union. Available at: https://ec.europa.eu/eurostat/ documents/3217494/5718905/KS-31-09290-EN.PDF/88eef9f7-c229-40de-b1cd$43126 \mathrm{bc} 4 \mathrm{a} 946$.

11- Faragher E, Cass M and Cooper C (2005): The relationship between job satisfaction and health: a meta-analysis. Occup Environ Med; 62(2): 105-12. 
12- Fell A, Noto H, Skogstad M, Nordby K, Eduard W, et al (2011): A cross-shift study of lung function, exhaled nitric oxide and inflammatory markers in blood in Norwegian cement production workers. Occup Environ Med; 68(11): 799-805.

13- Gholami A, Farsi M, Hashemi Z and Lotfabadi P (2013): Quality of life in nurses working in Neyshabur hospitals. Thrita Student Journal of Medical Sciences; 2(1): 94-100.

14- Gizaw Z, Yifred $B$ and Tadesse $T$ (2016): Chronic respiratory symptoms and associated factors among cement factory workers in Dejen town, Amhara regional state, Ethiopia. Multidisciplinary Respiratory Medicine; 11:13.

15- Kang W, Park W-J, Jang K-H, Lim H-M, Ann J-S, et al.( 2016): Comparison of anxiety and depression status between office and manufacturing job employees in a large manufacturing company: a cross sectional study. Ann Occup Environ Med; 28:47.

16- Kato M (2000): Research reports on stress in the workplace and its effects on health, Ministry of Health, Labor, and Welfare 'Study on prevention of workrelated disease' (in Japanese). Preventive Medicine and Public Health. Tokyo Medical University: Tokyo.
17- Kiecolt-Glaser J, Preacher K, MacCallum R, Atkinson C, Malarkey W, et al(2003): Chronic stress and age-related increases in the pro-inflammatory cytokine IL-6.PNAS; 100(15): 9090-5.

18- Kurban S, Çeçen D, Karabag N, Petek N and Çalkan S (2012): Effect of Work Lives of Nurses Working in Celal Bayar University Training and Research Hospital to their Life Qualities. Surgical Care and Life Quality Symposium; 237: 1462-7.

19- Luo H, Yang H, Xu X, Lin Yun L, Chen R, et al. (2016): Relationship between occupational stress and job burnout among rural to- urban migrant workers in Dongguan, China: a cross sectional study. BMJ Open; 6:1-8.

20- Manjula R, Praveena R, Clevin R, Ghattargi C, Dorle A, et al (2013): Effects of occupational dust exposure on the health status of Portland cement factory workers. International Journal of Medicine and Public Health; 3(3): 193:6.

21- Mauno S, Ruokolainen M and Kinnunen U (2013): Does aging make employees more resilient to job stress? Age as a moderator in the job stressor-well-being relationship in three Finnish occupational samples. Aging and Mental Health; 17(4): 411-22. 
22- Mohammadi H, Dehghan S, Golbabaei F, Roshani S, Pakzad R, et al (2017): Pulmonary Functions and Health-Related Quality of Life among Silica-Exposed Workers. Tanaffos; 16 (1): 60-7.

23- Morsy E (1995): Occupational health hazards secondary to inhaled dust particles in cement industry Assiut: master thesis. Assuit University.

24- Neghab M and choobineh A (2007): Work-related Respiratory Symptoms and Ventilatory disorders among employees of cement industry in shiraz, Iran. Journal of Occupational Health; 49: 273-8.

25- Nordby K, Fell AKM, Noto H, Eduard W, Skogstad M, et al. (2011): Exposure to thoracic dust, airway symptoms and lung function in cement production workers. European Respiratory Journal; 38(6): 1278-86.

26- Sakakibara H (2006): Relationship of obesity to job stress and eating behavior in male Japanese workers. International Journal of Obesity; 30: 528-33.
27- Srivastava K (2009): Urbanization and mental health. Ind Psychiatry J; 18(2): 75-6.

28- Stansfeld S, Rasul F, Head J and Singleton N (2011): Occupation and mental health in a national UK survey. Social Psychiatry and Psychiatric Epidemiology; 46: 101-10.

29- Thepaksorn P, Pongpanich S, Siriwong W, Chapman R and Taneepanichskul S (2013): Respiratory Symptoms and Patterns of Pulmonary Dysfunction among Roofing Fiber Cement Workers in the South of Thailand. Journal of Occupational Health; 55: $21-8$.

30- Wen C, Levy D, Cheng T, Hsu C and Tsai S (2005): Smoking behavior in Taiwan, 2001. Tob Control; 14: 51-5.

31- WHO (World Health Organization) (2019): Stress at the workplace. Available at: https://www.who.int/occupational_health/ topics/stressatwp/en/ ;accessed 30-3-2019. 
